\title{
HUBUNGAN PRILAKU PEMBERIAN MP-ASI DAN KEJADIAN DIARE DENGAN STATUS GIZI BAYI USIA 6-11 BULAN DI PUSKESMAS SIMPANG KAWAT KOTA JAMBI
}

\author{
Indah Eptika $^{1)}$, Djayusmantoko ${ }^{2)}$, Merita $^{3)}$ \\ ${ }^{1,2,3}$ Program Studi Ilmu Gizi STIKes Baiturrahim Jambi \\ Emailindaheptika27@gmail.com
}

\begin{abstract}
Provision of complementary feeding that is too early has an impact on the incidence of diarrhea. The purpose of this study was to determine the relationship between the behavior of giving complementary feeding and the incidence of diarrhea with the nutritional status of 6-11 month-old infants at the Primary Health Center of Simpang Kawat in Jambi City, 2019 years. This study used a cross sectional study design. The research sample is infants aged 6-11 months as many as 75 infants with accidental sampling technique. Collecting data through questionnaires and interviews with mothers and anthropometric measurements (Weight/Aged). Data was analyzed using univariate and bivariate test (chi-square). The result showed that the giving of complementary feeding was good (52.0\%), and the provision of complementary feeding was not good (48.0\%). The incidence of diarrhea was as much as $40.0 \%$ and not diarrhea as much as $60.0 \%$. Good nutritional status $(98.7 \%)$ and poor nutritional status $(1.3 \%)$. The chisquare test analysis showed that there is no correlation between the provision of complementary feeding with nutritional status in infants aged 6-11 months in (pvalue $=1,000$ ) and there is no relationship between the incidence of diarrhea with nutritional status in infants 6-11 months (p-value=0,400). It is recommended to heatlh officers to provide education to mothers related to giving complementary feeding and preventing incidence of diarrhea so as not to have an impact on the nutritional status of infants.
\end{abstract}

Keywords: Infants, Complementary Foods of Breastfeeding, Diarrhea, Nutritional Status

\begin{abstract}
ABSTRAK
Pemberian MP-ASI yang terlalu dini berdampak terhadap kejadian diare. Tujuan penelitian ini untuk mengetahui hubungan perilaku pemberian MP-ASI dan kejadian diare dengan status gizi Bayi Usia 6-11 bulan di Puskesmas Simpang Kawat Kota Jambi. Penelitian ini menggunakan desain cross sectional study. Sampel penelitian yaitu bayi berusia 6-11 bulan sebanyak 75 bayi dengan tehnik accidental sampling. Pengumpulan data melalui pengisian kuesioner dan wawancara kepada ibu serta pengukuran secara antropometri (BB/U). Analisis data menggunakan univariat dan bivariat (chi-square test). Pemberian MP-ASI baik sebanyak (52,0\%), dan pemberian MP-ASI kurang baik sebanyak $(48,0 \%)$. Kejadian diare sebanyak $(40,0 \%)$ dan tidak terjadi diare sebanyak $(60,0 \%)$. Status gizi baik $(98,7 \%)$ dan status gizi kurang $(1,3 \%)$. Analisis chi-square menunjukkan bahwa tidak ada hubungan pemberian MP-ASI dengan status gizi pada bayi 6-11 bulan ( $\mathrm{p}$-value $=1,000$ ) dan tidak ada hubungan kejadian diare dengan status gizi pada bayi 6-11 bulan (p-value=0,400). Disarankan kepada petugas kesehatan agar memberikan edukasi kepada ibu terkait pemberian MP-ASI dan pencegahan kejadian diare agar tidak berdampak pada status gizi bayi.
\end{abstract}

Kata Kunci: Bayi, MP-ASI, Diare, Status Gizi 


\section{PENDAHULUAN}

Gizi adalah faktor penting yang memegang peranan dalam siklus kehidupan manusia terutama bayi dan anak yang nantinya akan menjadi penerus bangsa. Faktor yang menentukan tingkat kesehatan dan kesejahteraan manusia adalah gizi. Salah satu langkah yang cukup strategis untuk menimbulkan motivasi ke arah perbaikan status gizi anak adalah melakukan pemberdayaan keluarga atau masyarakat (Depkes RI, 2006).

Pada waktu lahir, panjang badan bayi rata-rata adalah $50 \mathrm{~cm}$, tinggi badan $75 \mathrm{~cm}$ dicapai pada usia 1 tahun, $85 \mathrm{~cm}$ pada usia 2 tahun dan $100 \mathrm{~cm}$ yaitu 2 kali panjang lahir dicapai pada usia 4 tahun, dan pada usia 6 tahun tingginya berkisar 130 $\mathrm{cm}$. Dalam keadaan normal tinggi badan tumbuh bersama dengan pertumbuhan umur. Pengaruh defisiensi zat gizi terhadap tinggi badan baru akan tampak pada saat yang cukup lama. (Maryunani, 2010).

Program perbaikan gizi yang bertujuan meningkatkan jumlah dan mutu MP-ASI, diantaranya dapat dilakukan dengan pemberian MPASI kepada bayi dan anak usia 6-24 bulan dari keluarga miskin (Fatimah, 2010). Pemberian makanan pendamping ASI yang terlalu dini dapat menyebabkan bayi kurang selera untuk minum ASI. Sebaliknya pemberian makanan pendamping yang terlambat dapat menyebabkan bayi sulit untuk menerima makanan pendamping (Helmyti \& Lestariani, 2007).

Beberapa penelitian menyatakan bahwa masalah gizi pada bayi dan anak disebabkan kebiasaan pemberian ASI dan MP-ASI yang tidak tepat (segi kuantitas dan kualitas). Selain itu, para ibu kurang menyadari bahwa sejak bayi berusia 6 bulan sudah memerlukan MP-ASI dalam jumlah dan mutu yang baik (Hermina \& Nurfi, 2010). Pada usia 6 bulan, selain ASI bayi mulai bisa diberi makanan pendamping ASI, karena pada usia itu bayi sudah mempunyai refleks mengunyah dengan pencernaan yang lebih kuat. Dalam pemberian makanan bayi perlu diperhatikan ketepatan waktu pemberian, frekuensi, jenis, jumlah bahan makanan, dan cara pembuatannya. Adanya kebiasaan pemberian makanan bayi yang tidak tepat, antara lain : pemberian makanan yang terlalu dini atau terlambat, makanan yang diberikan tidak cukup dan frekuensi yang kurang (Maseko \& Owaga, 2012).

WHO (2001) menyebutkan bahwa ada $51 \%$ angka kematian anak balita disebabkan oleh pneumonia, diare, campak, dan malaria. Lebih dari separuh kematian tersebut (54\%) erat hubungannya dengan masalah gizi. Oleh karena itu prioritas utama penanganan utama adalah memperbaiki pemberian makan kepada bayi dan anak serta perbaikan gizi ibunya (Depkes RI, 2007). Semakin meningkatnya umur bayi, kebutuhan akan zat gizi semakin bertambah karena tumbuh kembang, sedangkan Air Susu Ibu (ASI) yang dihasilkan ibunya kurang memenuhi kebutuhan gizi. Oleh sebab itu mulai usia 6 bulan selain ASI, bayi mulai diberikan makanan pendamping air susu ibu (MP-ASI) agar kebutuhan gizinya terpenuhi. (Depkes RI, 2006). 
Makanan pendamping ASI adalah makanan untuk bayi selain ASI, sebagai penambah kekurangan ASI atau susu pengganti ASI. Pemberian makanan pendamping air susu ibu (MP-ASI) bayi tergantung sepenuhnya pada perawatan dan pemberian makanan oleh ibu. Bayi usia $>6$ bulan sudah diperkenalkan dan diberi makanan pendamping ASI karena produksi ASI mulai menurun dan tidak mencukupi kebutuhan fisiologis untuk tumbuh kembang (Eva Molika S, 2014).

Menurut hasil penelitian Itriani (2009) menyatakan bahwa MP-ASI diberikan kepada bayi saat berusia lebih dari 6 bulan karena bayi pada usia ini sudah memiliki sistem imunitas yang cukup kuat untuk melindungi dari berbagai macam penyakit dan sistem cerna yang lebih sempurna sehingga dapat mengurangi risiko alergi terhadap makanan. Data dari Pusat Pengembangan Gizi dan Makanan Departemen Kesehatan, melaporkan bahwa lebih dari $50 \%$ bayi di Indonesia mendapatkan makanan pendamping ASI pada usia kurang dari 1 bulan.

Beberapa penelitian dinyatakan bahwa keadaan kurang gizi pada bayi dan anak disebabkan karena kebiasaan pemberian MP-ASI yang tidak tepat dan ketidaktahuan ibu tentang manfaat dan cara pemberian MP-ASI yang benar sehingga berpengaruh terhadap sikap ibu dalam pemberian MP-ASI (Mahaputri, 2012).

Selama kurun waktu 1998 sampai 2014 terdapat sekitar 40 juta bayi mengalami kurang gizi dari keseluruhan 211 juta bayi yang ada. Meningkatnya jumlah anak bayi yang mengalami kurang gizi tersebut karena tidak terpenuhinya makanan beragam, bergizi dan berimbang (Depkes RI, 2013). Pada Tahun 2015 berdasarkan data dari Dinas Kesehatan Kota Jambi lebih kurang 26 bayi mengalami gizi buruk dan 286 bayi mengalami kekurangan gizi (Dinkes Jambi, 2015). Sebagian besar ibu belum memahami MP-ASI, sehingga makanan tersebut diberikan sejak usia 2 sampai 3 bulan pada bayi, padahal di usia tersebut system pencernaan bayi belum siap menerima asupan makanan selain ASI (Depkes RI, 2006).

Dampak pengenalan makanan pendamping ASI terlalu dini kepada diet bayi akan menurunkan frekuensi dan intensitas pengisapan bayi, yang akan merupakan risiko untuk terjadinya penurunan produksi ASI, resiko diare meningkat karena tidak sebersih ASI, kolikusus, alergi makanan dan sebagainya (Eva Molika S, 2014). Menteri pemberdayaan perempuan mengatakan sekitar 6,7 juta bayi atau 27,3\% dari seluruh bayi di Indonesia menderita kurang gizi. Hal ini akibat pemberian ASI dan MP-ASI yang salah seperti pemberian MP-ASI diniatau MP-ASI yang diberikan tidak sesuai dengan tahapan perkembangan pencernaan bayi (Depkes RI, 2006).

Berdasarkan Data Dinas Kesehatan Kota Jambi tahun 2017, menunjukan bahwa dari 20 puskesmas yang ada di Kota Jambi, Puskesmas dengan Kasus Diare Pada Usia $\geq 6$ Bulan $-<1$ Tahun terbanyak ada pada puskesmas simpang kawat Kota Jambi yaitu berjumlah $10 \%$ dan jumlah gizi kurang pada puskesmas paal merah II sebanyak 
7\%. Berdasarkan uraian di atas maka tujuan penelitian ini adalah untuk menganalisis hubungan lama pemberian ASI, penyakit infeksi dan faktor genetik dengan kejadian stunting di Wilayah Kerja Puskesmas Siulak Mukai Kabupaten Kerinci Tahun 2019.

\section{METODE PENELITIAN}

Penelitian ini bersifat deskriptif dengan desain cross sectional yaitu penelitian yang dilakukan dalam satu waktu, populasi penelitian ini adalah bayi usia 6-11 bulan berjumlah 336 bayi dan jumlah sampel sebanyak 75 responden tehnik pengambilan sampel penelitian ini mengunakan tehnik accidental sampling (Riyanto,2010). Penelitian ini dilakukan pada bulan Mei 2019, data diperoleh dengan menggunakan kuesoner MP-ASI dan diare sebagai alat pengumpulan data memalui pengisian kuesioner dan wawancara kepada ibu serta pengumpulan status gizi secara antropometri (BB/U). Anlilis data dilakukan dengan mengunakan analisis univariat dan bivariat dengan uji chi-square.

\section{HASIL DAN PEMBAHASAN}

Gambaran variabel penelitian dapat dilihat pada Tabel 1 di bawah ini.

Tabel 1. Distribusi Frekuensi Status Gizi, Pemberian MP-ASI, dan Kejadian Diare pada Bayi Usia 6-11 Bulan di Puskesmas Simpang Kawat Kota Jambi Tahun 2019

\begin{tabular}{|c|c|c|c|}
\hline No & Variabel & $\mathrm{n}$ & $\%$ \\
\hline \multicolumn{4}{|c|}{ Status Gizi } \\
\hline 1 & Baik & 74 & 98,7 \\
\hline \multirow[t]{2}{*}{2} & Kurang Baik & 1 & 1,3 \\
\hline & Jumlah & 75 & 100 \\
\hline \multicolumn{4}{|c|}{ Pemberian MP-ASI } \\
\hline 1 & Baik & 39 & 52,0 \\
\hline \multirow[t]{2}{*}{2} & Kurang Baik & 36 & 48,0 \\
\hline & Jumlah & 75 & 100 \\
\hline \multicolumn{4}{|c|}{ Kejadian Diare } \\
\hline 1 & Terjadi diare & 30 & 40,0 \\
\hline \multirow[t]{2}{*}{2} & Tidak terjadi diare & 45 & 60,0 \\
\hline & Jumlah & 75 & 100 \\
\hline
\end{tabular}

Gizi sangat berperan dalam tumbuh kembang anak. Tujuan pemberian gizi yang baik adalah mencapai tumbuh kembang anak yang adekuat. Pada bayi dan anak, kekurangan gizi akan menimbulkan gangguan pertumbuhan dan perkembanagan yang apabila tidak diatasi secara dini akan berlanjut hingga dewasa. Usia 0-24 bulan merupakan masa kritis dalam pertumbuhan dan perkembanagan anak, karena dimasa inilah periode tumbuh kembang anak yang paling optimal baik untuk intelegensi maupun fisiknya. Periode ini dapat terwujud apabila anak mendapatkan asupan gizi sesuai dengan kebutuhannya secara optimal (Soetjiningsih dalam Lestari, 2012).

Status gizi yang baik pada bayi dapat terjadi jika tubuh dalam keadaan normal (sehat) dan mengkonsumsi makanan dengan 
kebutuhan akan zat-zat gizinya terjamin. Gizi baik dintandai dengan pertumbuhan berat badan anak sesuai dengan umur. Apabila pertumbuhan berat badan berlebih dari umur anak, maka dikatakan anak mengalami gizi lebih. Bayi juga dapat mengalami gizi kurang apabila tidak memperoleh cukup makanan atau konsumsi energy dan protein yang kurang dari makanan sehari-hari dan pertumbuhan kritis (Datesfordate, 2017).

Sebanyak 39 responden dengan pemberian MP-ASI baik $(52,0 \%)$. Hal ini terjadi karena sebagian besar ibu memberikan pemberian MP-ASI sesuai dengan ketentuan yang dianjurkan untuk anak. Dikarenakan pendidikan ibu sebagian besar sudah tinggi, disamping itu juga dengan bertambahnya kemajuan teknologi ibu dengan mudah dapat untuk mengakses informasi dari manapun. Hal itu yang mendorong ibu bisa menyediakan pemberian MP-ASI dengan baik. Didapatkan hasil dari peneltian di atas masih ada nya ibu dengan pemberian MP-ASI kurang baik. Banyak hal lain yang dapat menunjang pemberian MP-ASI kurang baik diantaranya adalah kurang nya keinginan orang tua untuk mencari tahu tentang apa-apa saja makanan yang baik untuk anaknya.

Demikian pula penelitian yang dilakukan oleh Merita et al. (2017), juga menunjukkan bahwa sebagian besar balita memiliki pemberian MPASI yang baik. Hal ini dikarenakan ibu dari balita pada studi sebagian besar sebagai Ibu Rumah Tangga (IRT) sehingga memiliki waktu lebih dalam menyiapkan makanan yang baik untuk balita.
Pemberian

Makanan

Pendamping ASI (MP-ASI) yang tepat, baik jumlah dan kualitasnya akan berkonsekuensi terhadap status gizi bayi. MP-ASI yang baik tidak hanya cukup mengandung energi dan protein, tetapi juga mengandung zat besi, vitamin A, asam folat, vitamin B serta vitamin dan mineral lainnya (Yetty, 2005). MP-ASI, yang baik adalah kaya energi, protein, mikronutrien, mudah dimakan anak, disukai anak, berasal dari bahan makanan lokal dan terjangkau, serta mudah disiapkan (Tim Admin HHBF, 2015).

Penelitian ini juga menemukan bahwa dari 75 responden sebanyak $45(60,0 \%)$ bayi dengan tidak terjadi diare. Hal ini sejalan dengan penelitian yang dilakukan oleh Solikatun,dkk 2013 juga menujukan bahwa sebagian besar tidak terjadi diare $(60 \%)$ dan ini juga sejalan dengan penelitian yang dilakukan Masrul, dkk. 2013. Juga menunjukan bahwa sebagian besar tidak terjadi diare $(74,5 \%)$.

Berdasarkan hasil penelitian diatas masih banyak anak yang tidak terjadi diare hal itu disebabkan karena faktor pemberian MP-ASI sudah baik. Dan di dukung oleh indikator ibu memberikan makanan anak bayi bervariasi dari pagi hingga sore, setiap hari anak diberi buah dan dalam memberikan makanan pokok anak bayi, apakah ibu menyuapi sendiri. Hal yang demikian menyebakan tidak terjadinya diare pada anak mereka. 


\section{Hubungan Pemberian MP-ASI dengan Status Gizi Bayi Usia 6-11 Bulan}

Analisis hubungan pemberian ASI dengan status gizi dapat dilihat pada Tabel 2 di bawah ini.

Tabel 2. Hubungan Pemberian MP-ASI dengan Status Gizi Bayi Usia 6-11 Bulan di Puskesmas Simpang Kawat Tahun 2019

\begin{tabular}{|c|c|c|c|c|c|c|c|c|}
\hline \multirow{3}{*}{ No } & \multirow{3}{*}{$\begin{array}{c}\text { Pemberian MP- } \\
\text { ASI }\end{array}$} & \multicolumn{4}{|c|}{ Status Gizi } & \multirow{2}{*}{\multicolumn{2}{|c|}{ Jumlah }} & \multirow{3}{*}{$p$-value } \\
\hline & & \multicolumn{2}{|c|}{ Gizi Baik } & \multicolumn{2}{|c|}{ Gizi Kurang } & & & \\
\hline & & $\mathrm{n}$ & $\%$ & $\mathrm{n}$ & $\%$ & $\mathrm{n}$ & $\%$ & \\
\hline 1 & Baik & 38 & 97,4 & 1 & 2,6 & 39 & 100 & 1,000 \\
\hline 2 & Kurang Baik & 36 & 100 & 0 & 0 & 36 & 100 & \\
\hline & Jumlah & 74 & 98,7 & 1 & 1,3 & 75 & 100 & \\
\hline
\end{tabular}

Tabel 2 di atas menunjukkan bahwa dari 39 ibu yang pemberian MP-ASI kurang baik sebagian besar memiliki bayi dengan status gizi baik (100\%), sementara itu, ibu yang pemberian MP-ASI baik sebagian besar juga memiliki status gizi baik (97,4\%). Analisis chi-square menunjukan bahwa tidak ada hubungan yang signifikan antara pemberian MP-ASI dengan status gizi pada bayi umur 6-11 bulan di Puskesmas Simpang Kawat ( $p$-value 1,000). Hasil ini sejalan dengan penelitian yang dilakukan oleh Destriatania (2016) yang menyatakan bahwa tidak ada hubungan yang bermakna pemberian MP-ASI dengan status gizi $(\mathrm{p}=0,08)$.

MP-ASI merupakan makanan tambahan bagi bayi. Makanan ini harus menjadi pelengkap dan dapat memenuhi kebutuhan bayi. Hal ini menunjukkan bahwa MP-ASI berguna untuk menutupi kekurangan zat gizi yang terkandung dalam ASI. Dengan demikian, cukup jelas bahwa peranan makanan tambahan bukan sebagai pendamping ASI tetapi untuk melengkapi atau mendampingi ASI (Sari, 2014). Status gizi sangat berpengaruh terhadap pertumbuhan dan perkembangan balita. Secara fisik anak yang menderita gizi kurang akan mengalami gangguan pertumbuhan dan mudah terkena penyakit infeksi. Penyebab gangguan pertumbuhan diantaranya disebabkan karena pola konsumsi makanan pendamping ASI (MP-ASI) yang kurang benar dan kurang tepat. Pemberian MP-ASI sebelum usia 6 bulan ditinjau dari perkembangan sistem pencernaan belum siap menerima makanan semi padat dan berisiko terkena diare. MP-ASI yang tidak diberikan pada waktu dan jumlah yang tepat maka dapat menurunkan status gizi (Destriatania, 2016).

Oleh karena itu, disarankan kepada pihak terkait terutama ibu dalam hal ini untuk lebih meningkatkan dan memperhatikan pemberian MP-ASI pada bayi, karena pemberian MP-ASI akan mempengaruhi status gizi bayi. Status gizi merupakan hal yang harus mendapatkan perhatian dalam pertumbuhan dan perkembangan anak. Semakin baik makanan yang di konsumsi bayi maka semakin baik pula status gizi bayi.

\section{Hubungan Kejadian Diare dengan Status Gizi Bayi Usia 6-11 Bulan}

Tabel 3 menunjukkan bahwa dari dari 45 (100\%) bayi yang tidak 
terjadi diare semua bayi memiliki status gizi baik (100\%), demikian pula dari 30 bayi yang terjadi diare hampir semua bayi memiliki status gizi baik $(96,7 \%)$. Terdapat $1(3,3 \%)$ mengalami gizi kurang. Analisis chisquare menyatakan bahwa tidak ada hubungan yang signifikan antara antara kejadian diare dengan status gizi pada bayi umur 6-11 bulan di Puskesmas Simpang Kawat ( $p$-value 0,400). Hasil ini sejalan dengan penelitian yang dilakukan oleh Masrul (2013) yang menunjukkan hasil bahwa tidak terdapat hubungan yang signifikan antara kejadian diare dengan status gizi dengan ( $p$-value 0,742 ).

Tabel 3. Hubungan Kejadian Diare dengan Status Gizi Bayi Usia 6-11 Bulan di Puskesmas Simpang Kawat Tahun 2019

\begin{tabular}{clccccccc}
\hline \multirow{2}{*}{ No } & Kejadian Diare & \multicolumn{4}{c}{ Status Gizi } & \multirow{2}{*}{ Jumlah } & \multirow{2}{*}{ p-value } \\
\cline { 3 - 7 } & & \multicolumn{3}{c}{ Gizi Baik } & \multicolumn{2}{c}{ Gizi Kurang } & & \\
\cline { 3 - 7 } & & $\mathbf{n}$ & $\mathbf{\%}$ & $\mathbf{n}$ & $\mathbf{\%}$ & $\mathbf{n}$ & $\mathbf{\%}$ & \\
\hline 1 & Tidak terjadi & 45 & 96,7 & 0 & 0 & 45 & 100 & 1,000 \\
& diare & & & & & & & \\
\multirow{2}{*}{2} & $\begin{array}{l}\text { Terjadi diare } \\
\text { Jumlah }\end{array}$ & 29 & 100 & 1 & 3,3 & 30 & 100 & \\
\hline
\end{tabular}

Penyebab gizi kurang tidak hanya disebabkan karena makanan yang tidak sesuai, tetapi juga karena penyakit. Anak yang mendapat makanan yang baik tetapi karena sering sakit diare atau demam dapat menderita kurang gizi. Diare adalah peningkatan frekwensi atau penurunan konsistensi feses. Diare persisten yaitu diare yang pada mulanya bersifat akut tetapi berlangsung lebih dari 14 hari, kejadian dapat dimulai dengan diare cair atau disentri mengakibatkan kehilangan berat badan yang nyata, dengan volume feses dalam jumlah yang banyak sehingga mengalami dehidrasi (Sodikin,2012 dalam Fatmawati, 2017). Demikian juga dengan anak yang makannya tidak cukup baik maka daya tahan tubuh makin melemah dan mudah terserang penyakit. Kenyataan secara bersamasama baik makanan maupun penyakit merupakan penyebab dari kurang gizi (Datesfordate, 2017).

Status gizi buruk berdampak terhadap menurunnya produksi zat antibodi dalam tubuh. Penurunan zat antibodi ini mengakibatkan mudahnya bibit penyakit masuk ke dalam dinding usus dan mengganggu produksi beberapa enzim pencernaan makanan dan selanjutnya penyerapan zat-zat gizi yang penting menjadi terganggu. Keadaan ini dapat memperburuk status gizi anak. Balita dengan gizi yang kurang akan lebih mudah terserang penyakit bahkan serangannya lebih lama dibandingkan balita dengan gizi normal karena faktor daya tahan tubuh yang kurang (Hati, 2015).

\section{SIMPULAN}

Berdasarkan hasil penelitian maka dapat disimpulkan bahwa responden dengan status gizi baik sebanyak $98,7 \%$ dan status gizi kurang sebanyak $1,3 \%$. Pemberian MP-ASI baik sebanyak 52,0\%, dan pemberian MP-ASI kurang baik sebanyak 48,0\%. Kejadian diare sebanyak 40,0\% dan tidak terjadi diare sebanyak $60,0 \%$. Hasil analisis chi-square menunjukkan tidak ada 
hubungan antara pemberian MP-ASI dengan status gizi pada bayi 6-11 bulan $(p=1,000)$ dan tidak ada hubungan antara kejadian diare dengan status gizi pada bayi 6-11 bulan $(p=0,400)$.

\section{SARAN}

Berdasarkan hasil penelitian ini disarankan agar ibu dalam hal ini memperhatikan makanan yang diberikan kepada bayi, karena makanan yang tidak sehat akan memicu terjadinya diare, dan diare akan berdampak pula pada status gizi bayi. Ketiga komponen tersebut memiliki keterkaitan yang sangat erat antara satu dan yang lainnya.

\section{DAFTAR PUSTAKA}

1. Ananingsih, 2014. Hubungan Jenjang Pendidikan Ibu Dengan Kebiasaan Memberikan MPASI. Jurnal Ners Dan Kebidanan 1 (2).

2. Azwar, (2000), Mengenal Makanan-makanan Pendamping ASI.

http://ilmukeperawatan.wordpres s.com. di akses pada tanggal 2 April 2016

3. Christy, 2014. Faktor Yang Berhubungan Dengan Kejadian Dehidrasi Diare Pada Balita Di Wilayah Kerja Puskesmas Kalijudan. Jurnal Berkala Epidemiologi 2 (3) Issn 297:308.

4. Destriatania, 2016. Analisis Pemberian MP-ASI Dengan Status Gizi Pada Anak Usia 1224 Bulan Di Wilayah Kerja Puskesmas Lesung Batu, Empat Lawang. Kesehatan Masyarakat : Universitas Sriiwijaya. ISSN : 2086-6380
5. Detesfordate, 2017. Hubungan Pemberian Makanan Pendamping Air Susu Ibu (MPASI) Dengan Status Gizi Bayi Pada Usia 6-12 Bulan Di Wilayah Kerja Puskesmas Bahu Manado. Ilmu Keperawatan : Universitas Sam Ratulangi. EJournal Keperawatan 5 (2).

6. Dinas Kesehatan Kota Jambi. (2015). Cakupan Pembinaan Gizi Pada Bayi di 20 Puskesmas Kota Jambi Tahun 2015

7. Djamil,dkk 2010, Hubungan Antara Pola Pemberian Makanan Pendamping ASI (MP-ASI) Dan Status Gizi Balita Usia 6-24 Bulan Diwilayah Kerja Pukesmas Gedongtengen Yogyakarta. Kesmas 4 (2) ISSN : 1978-0575

8. Eva Molika S, 2014. Pedoman Makanan Pendamping Asi. Raja Grafindo Persada: Jakarta.

9. Hasanah dkk, 2015. FaktorFaktor Yang Berhubungan Dengan Pemberian Makanan Pendamping ASI Dini. JOM 2 (1)

10. Hati dkk, 2015. Gambaran Status Gizi Anak 12-24 Bulan Di Puskesmas Mergangsan Kota Yogyakarta Tahun 2015: Tinjauan Riwayat Pemberian ASI Eksklusif Dan Kejadian Penyakit Infeksi. Jurnal Gizi Dan Dietetik Indonesia 3 (3), September 2015: 149-154.

11. Hidayat. (2007). Metode Penelitian Keperawatan dan Tekhnik Analisa Data. Jakarta: Salemba Medika

12. Husaini dan Anwar. (1984). Asuhan Kebidanan Ibu Nifas dan Menyusui. TIM : Jakarta 
13. Itriani, A. (2009). Jurnal Hubungan Antara Tingkat Pendidikan dan Pengetahuan Ibu Balita dengan Pola Pemberian MP-ASI pada Anak Usia 6-24 Bulan di Posyandu Menur IV Kecamatan Jebres Surakarta.

14. Janiwarty \& Pieter, 2012. Pendidikan Psikologi Untuk Kebidanan, Suatu Teori Dan Terapannya. Rapha Publishing : Yogyakarta

15. Krisnatuti. (2000). Makanan Sehat Bayi dan Balita. PT. Dian Rakyat: Jakarta.

16. Lestari dkk. (2012). Hubungan pemberian Makanan Pendamping Asi (MP-ASI) dengan Status Gizi Anak Usia 13 Tahun di Kota Padang Tahun 2012.

17. Masrul dkk, 2015. Hubungan Diare Dengan Status Gizi Balita Di Kelurahan Lubuk Buaya Kecamatan Koto Tangah Kota Padang. Jurnal Kesehatan Andalas.

18. Merita, M., Sari, M. T., \& Hesty, H. (2017). The positive deviance of feeding practices and carring with nutritional status of toddler among poor families. KEMAS: Jurnal Kesehatan Masyarakat, 13(1), 106-112.

19. Muchtadi. (1994). Inisiasi Menyusui Dini, ASI eksklusif dan Manajemen Laktasi. TIM : Jakarta

20. Notoatmodjo, S. (2007). Promosi Kesehatan \& Ilmu Perilaku. Rineka Cipta : Jakarta 21. 2012.

Metodologi Penelitian Kesehatan. Rineka Cipta : Jakarta
22. Pakaya dkk, 2014. Hubungan Pengetahuan, Pendidikan Dan Pekerjaan Idu Dengan Pemberian Makanan Pendamping ASI (MP-ASI) Pada Bayi Di Puskesmas Bahu Kecamatan Malalayang Kota Manado. Jurnal ilmiah bidan 2 (2) ISSN 2339:1731.

23. Pertiwi, 2014. Hubungan Pemberian Makanan Pendamping Asi (MP-ASI) Dengan Status Gizi Anak Usia 1-3 Tahun Di Kota Padang Tahun 2012.

24. Rochimiwati, 2013. Hubungan Pola Pemberian MP-ASI Dengan Status Gizi Anak Usia 6-23 Bulan Di Wilayah Kerja Pesisir Kecamatan Tallo Kota Makassar. Jurnal Gizi Politeknik Kesehatan : Kemenkes Makasar.

25. Roesli. (2008). Jurnal Hubungan pengetahuan dengan sikap pemberian ASI eksklusif pada ibu menyusui. Sumatra Utara. USU

26. Solikatun, 2013. Hubungan Pemberian Makanan Pendamping ASI Dini Dengan Kejadian Diare Pada Bayi Usia Kurang 6 Bulan Di Wilayah Kerja Puskesmas Grabang II Kabupaten Magelang Tahun 2013. Skripsi Stikes Guna Bangsa : Yogjakarta.

27. Tina Yuli Fatmawati, Iin Indrawati, Ariyanto. (2017). Analisis Penggunaan Air Bersih, Mencuci Tangan, Membuang Tinja Dengan Kejadian Diare Pada Balita. Endurance Journal, 2 (3)(Health Community), 294302.

https://doi.org/http://doi.org/10.2 2216/jen.v2i3.2245 